\title{
Oral Communication Apprehension Among ESP Students in Algeria
}

\author{
Naimi Amara \\ Department of English, Hassiba Benbouali University, Chlef, Algeria
}

Email address:

n.amara a univ-chlef.dz

\section{To cite this article:}

Naimi Amara. Oral Communication Apprehension Among ESP Students in Algeria. Arabic Language, Literature \& Culture. Vol. 3, No. 3, 2018, pp. 22-28. doi: 10.11648/j.allc.20180303.11

Received: August 4, 2018; Accepted: September 7, 2018; Published: October 9, 2018

\begin{abstract}
Communication Apprehension has attracted a lot of research especially about students' behaviour in the classroom and ever-increasing body of research has accumulated indicating that there is a pervasive relationship between this communication variable and various aspects of the academic experience. The main purpose of this article is to examine the level of Communication Apprehension (CA) among Third-Year Political Science students studying English for Specific Purposes (ESP) at Chlef University, and then investigate the main factors that lead to their CA in the ESP classroom. For the purpose of the study, the researcher used a mixed research method. The instruments that were used for data collection in the study are a questionnaire administered to 50 students and an interview conducted with 4 ESP teachers. The findings of the study revealed that most students had high level of CA with the relative contribution of two main reasons: instructional and psychological factors to the situation. Finally, some suggestions and recommendations on how to reduce communication apprehension among ESP students and improve their speaking skills were stated. Communication apprehension is a phenomenon that needs to be further investigated in the context of Political Sciences where students might be involved in situations where various cognitive and cultural elements work together.
\end{abstract}

Keywords: Communication Apprehension, English for Specific Purposes, Oral Communication, Political Science

\section{Introduction}

In the ESP context, students' success in getting a job is mainly based on their demonstration of communication skills. Different professions have different communication skills. However, for Politics, effective oral communication skills are the most vital part of their practice. It is obvious that having good oral communication skills is valuable for both classroom management and obtaining employment when graduated. Communication Apprehension (CA), which is our exact area of inquiry, stands as a real barrier to effective communication. There are two types of CA: Writing and Oral CA. Among all types, oral CA is considered to be the most important aspect and it happens due to an intense personal fear or anxiety about communicating.

There are two types of CA: writing and oral CA. Among all types, oral $\mathrm{CA}$ is considered to be the most important aspect and it happens due to an intense personal fear or anxiety about communicating. [1] In other words oral CA is the lack of capability to communicate verbally with people, which results in an ineffective communication. According to
Berger, McCroskey and Baldwin, Communication Apprehension is "the way a person feels about communication, not how they communicate". [2] They also stress that the fear of anxiety could be due to any of the following reasons: lack of proficiency in the target language, lack of practice, in security or any pr- programmed pattern. James McCroskey and Virginia Richmond report that nearly $95 \%$ of Americans surveyed said that they have some degree of anxiety about communicating in some situations. [3]

Many researchers have pointed out that the skill producing most anxiety is speaking. [4] Teachers of English at the department of Political Sciences at Chlef University complain about the level of their students' communication skills mainly the speaking skill. They say that they ignore the real factors that contribute to their students' communication apprehension. They notice that their students are reticent in speaking inside the classroom in presence of their peers. Their students tend to avoid expressing orally their personal ideas and hesitate to participate and respond to their teacher's questions even if they do know the exact answers. 


\subsection{Objectives}

1. Investigating the main factors that lead to $\mathrm{CA}$ in the Third Year Political Sciences' classroom.

2. Suggesting some solutions to cope with the students' $\mathrm{CA}$ and improve their speaking abilities.

\subsection{The Research Questions}

1. What are the main factors that lead to communication apprehension in the Political Sciences' classroom from the students' point of view?

2. What are the main factors that lead to communication apprehension in the Political Sciences' classroom from the teachers' point of view?

\subsection{The Research Hypotheses}

The researcher hypothesises the following:

Teachers and students will state different factors that lead to CA inside the Political Sciences' classroom.

Social and cultural factors may be mentioned by the students and/or teachers as the main factors that lead to the students speaking anxiety besides the instructional and psychological factors.

\section{Research Tools and Population}

Two instruments were used under this descriptive research. A questionnaire was administered to 50 (30 female and 20 male) students and an interview was conducted with the 04 teachers of English who taught all the third year classes.

\subsection{Students' Questionnaire}

The questionnaire was used to know some of the main factors that lead to students' apprehension in the ESP classroom. It was divided into two sections:

A. The Instructional Factors and B. The Psychological Factors:

\subsection{Teachers' Interview}

The aim from this interview was to deal with the phenomenon (students' speaking anxiety) from a different point of view (that of the students). Teachers were asked different questions. Each question aimed at highlighting some of the students' obstacles in speaking the English language and the possible factors that lead to their communication apprehension.

\section{Results and Discussion}

The main results were grouped and classified under the two research questions:

\subsection{First Research Question Results}

\subsubsection{The Instructional Factors}

The results showed that the students' responses for the
Instructional Factors Domain were moderate with a percentage of $68.75 \%$.

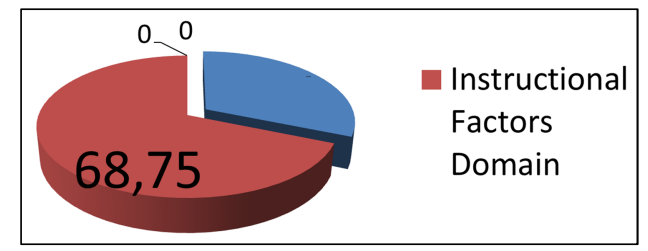

Figure 1. The Results of the Instructional Factors Domain.

The students ranked the items which are concerned with the teaching of ESP in their classroom at the first position. The fact of making mistakes, time constraints, no English exposure outside the classroom, translation from English to Arabic or vice versa, focussing only on the writing and reading skills, and being tested only in the written form are all factors which contribute to students' CA.

In general, the responses tended to fall into the following categories:

The question of who should teach ESP students:

The question of who is qualified to teach ESP courses rises strongly in students' answers. All the students ranked strongly on item (18) "We can benefit from the teacher who is specialised in the field (Political Sciences) more than an EFL teacher.)" Moreover, those students think that their teachers teach them general English and not ESP (item: 11). Discipline specialist teachers with an adequate mastery of English are preferred over EFL teachers who lack knowledge of the specialized field of study. It is known that the most important aim of ESP courses in general is to help the students understand the specialized texts of their textbooks. There are many terms, notions, and topics in these texts that should be taught by teachers of the same speciality and not by EFL teachers. In fact, in many cases ESP students find themselves more knowledgeable in their field of study than their EFL teachers because they are studying this field for many years and sometimes from their secondary education. Therefore, teachers of English, in order to facilitate their ESP classes, need to acquire some subject knowledge of their students' field of study (Politics for example).

The importance of the human factors which involves teacher-student relationships, and motivation. It is understood that if teachers' attitudes in the class are positive, their students react positively toward the teaching situation. For example, the teachers' friendly ways in the classroom (item2) and the fact that there are grades for classroom participation (item 4) makes students participate in the class. This indicates the effect of encouragement and friendly responses on students. However, students expect their teachers to use L1 (Arabic) to help them understand the lesson better and teachers often fall in this mistake in which they turn to translators of the English language to Arabic to facilitate the tasks for their students. This Grammar Translation Method is widely spread at the department of Political Sciences and in most Algerian Universities especially when dealing with ESP classes. 
The importance of an existing text book and time. The results show that there is no English textbook provided to the students either by the Ministry of Higher Education or by the teachers (item 15). This indicates that there is a need to provide textbooks and activities that enable students to practise oral skills. Most students responded that the time of the class also affected their participation since they tended to be less active during the afternoon classes (item 9). Other responses indicate that one hour and a half of learning English per week is not enough (item 8). Some activities need more time to be covered, therefore classroom oral activities are neglected. This result corresponds with Strevens and Izzo who stressed the importance of time in determining foreign language proficiency and achievement. [5, 6]

The importance of the situational (physical) factors. Despite the fact that the English class is not over crowded according to the students' point of view, only few students can participate in each class does not facilitate teachersstudents' interaction as well as students-students' interaction. Besides, students need more sessions since time is limited. Working with 25 students for each responded negatively on item (19), which indicates that audio-visual aids in the class were not used.

Classroom activities in large classes are neglected since they are time-consuming and the teacher is under pressure to keep up with the curriculum. Overcrowded classes do not give the students equal opportunities to participate in EFL classroom activities. They should therefore include audiovisual aids to help students be motivated and speak English at ease with a limited amount of tension and stress. This result is in accordance with Stevens who mentioned the importance of the computer in creating a non-threatening environment and facilitating language learning and communication. [7]

\subsubsection{The Psychological Factors}

The results show that the students' responses in the psychological factors domain are moderate with a percentage of $(62.8 \%)$.

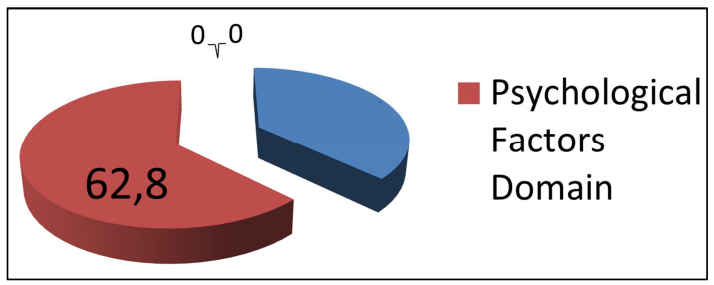

Figure 2. The Results of the Psychological Factors Domain.

It is obvious from the students' responses that teachers' gender is not considered as a variable that might contribute to students' Communication Apprehension (Items: 14, 15) Communication apprehension or speaking anxiety for them is a phenomenon which happens to everybody and in front of any person (male or female).

The responses tended to fall into the following categories:

Students' preference of a specialist discipline teacher over an EFL one:

This preference comes from a merely psychological point of view. Most students think that they can benefit from a specialist discipline teacher (who has an adequate level of English) more than an EFL one who lacks knowledge in the specialised field. They think that those EFL teachers can teach only General English (GE) and not ESP. This idea whether it is right or wrong, has psychological effects on students' perception and motivation towards the English lessons taught to them.

Fear of making mistakes: Most students are afraid of making mistakes in front of their peers and teachers (Item 25: $82 \%$ ). This obvious source of tension that causes uncertainty comes from an individual's perception of his or her language ability. Students remain silent in order to avoid failure. This is due to their belief that they lack the ability and the skill to speak coherent English. Students prefer to remain silent or speak in a subdued voice due to their consciousness of their limitation in the new language. The most important reason why students tend to be silent is the psychological pressure of making mistakes in the presence of their classmates and the second reason is their poor vocabulary.

Fear of negative evaluation in the classroom: Students responded positively to item (13:I feel relaxed to speak English when I prepare). They are aware that their preparation prevents negative evaluation and this leads to relaxation. Lack of confidence occurs when students are not prepared. The teacher must be patient with learners and pay special attention to shy or silent students. $\mathrm{S} / \mathrm{He}$ should reduce students' anxiety. By bridging the gap with his/her students, the teacher will inspire confidence and relaxation in them. Teachers should encourage the students to speak freely inside and outside the classroom.

Afraid of being laughed at or being criticized by others:

Due to inaccurate pronunciation or because they are timid in nature and shy to speak in front of male or female students; therefore they like to sit in the back row (Item: 37). The results of this study are in accordance with Price and Horwitz et al who agreed that among foreign language students, classroom participation and communication with people are the causes of CA because of the fear of ridicule etc. $[8,9]$, However, speaking a foreign language in front of their peers resulted in the most anxiety that interferes with their learning.

In general, the results of the psychological factors are in accordance with Krashen who stated that, "a low effective filter corresponds to high motivation, self-confidence, and a lack of anxiety.". [10] Therefore, teachers should create a safe and friendly learning environment that contributes to a low filter.

\subsection{Second Research Question Results}

The teachers' point of view comes in accordance with that of their students except in some details or interpretations. The teachers grouped these factors into instructional and psychological ones. They mentioned some of the causes of communication apprehension by referring to:

a-Students' low level before entering university or high school entrance exams 
b-Poor training in the oral skills

c-Students' psychology: (demotivation, unwillingness, perception, lack of interest....)

d-Time constraints which lead to students' stress and anxiety when speaking English

e-Students' conversation ability

f-Lack of preparation and practice inside and outside the classroom

g-Students' perception about the importance of English

$\mathrm{h}$-Absence of the audiovisual aids and multimedia

i-Lacking the minimal amount of general vocabulary/specialized vocabulary which enables them to speak simple English.

\section{Suggestions and Recommendations}

On the basis of the findings of this study, the researcher proposes some psychological and instructional suggestions to reduce the learners' speaking anxiety as well as improving the quality of the students' speaking skills:

1-Teachers should acknowledge the existence of the feelings of anxiety among the students while speaking the English language.

2-Bridging the gap between the EFL teachers and their "content specialized students".

3-EFL teachers and content specialist teachers should have a high level of co-operation between them to prepare the teaching material before using it in the classroom.

4-Promoting meaningful communicative exchanges in the ESP classroom

5-Creating a low, friendly and supportive classroom environment.

6-The use of gentle methods for error correction.

7-Increasing students' self esteem and self confidence

8- The reinforcement of the material to facilitate acquisition and feedback

9-The selection of interesting topics for class discussion and exercises

10 -Increasing the spirit of "team work" and "cooperative learning" among the students

11- There should be a high level of co-operation between EFL teachers and content specialist teachers to prepare the teaching material before using it in the classroom.

12- Training courses should be conducted for ESP teachers to enable them develop their students' learning strategies, without ignoring or neglecting their (students) learning preferences and learning styles.

13- An appropriate methodology should be adopted for teaching the four language skills. Activities such as role-play, information gap, surveys, group discussion...etc should be made part of the course to improve the students' speaking skills..

14- We should support students' sharing anxiety experience either between students, or between students and teachers.

15- Teachers should increase the use of the computer and the internet in the ESP classroom. The use of such material provides not only feelings of security and motivation but also real life situations which are likely to promote communication.

\section{Conclusion}

Oral communication skills are essential for success in all study areas and CA has negative effects on classroom participation and academic success since many teachers reward students who take part in classroom discussion by awarding them good marks for classroom participation. The attempt along this study was to identify the level of student' $\mathrm{CA}$ and then investigate the main factors that lead to CA among final year Political Sciences' students. As it was hypothesised, it is found from the results that there is a high level of CA among the students and that their speaking apprehension in the ESP classroom is a result of combination of instructional and psychological factors. These factors are interrelated and intersect. A surprising thing which attracted the researcher's attention was that both teachers and students agreed on the same factors that lead to the students' apprehension in the ESP classroom; though, they were different in the interpretations and explanations of these factors.

Teachers feel obliged to perform a difficult task which needs more efforts and several techniques to reach the peak of an effective communication; however, students are only trained to read and write the target language without giving much importance to the speaking skill which becomes the main obstacle the students fail to perform. The reason why, the researcher decided to undertake an investigation to seek for the main reasons which contribute to the students' speaking anxiety and try to find solutions that enable teachers to help students overcome the problem of apprehension and improve their speaking abilities.

At the end of this work, the researcher would remind that this study is a humble step towards a deep and concise future study which looks for the real factors which lead to studentse apprehension and reticence in the ESP classroom. Other studies with bigger populations and more research tools would probably reach better results and thus provide teachers who suffer from their students" silence and apprehension with more techniques and strategies to overcome the problem of students' speaking anxiety. 


\section{Appendix}

\section{Appendix 1:}

\section{Instructional Factors:}

Students' Questionnaire: Factors which cause students' CA

Dear Student,

Table 1. Instructional Factors causing students' Communication Apprehension (CA)

\begin{tabular}{|c|c|c|c|c|c|c|}
\hline $\mathbf{N}^{\circ}$ & Item & SA (5) & $A(4)$ & $\mathbf{U}(3)$ & D (2) & SD (1) \\
\hline 1 & My teacher of English teaches us general English and not EAP/ESP. & & & & & \\
\hline 2 & $\begin{array}{l}\text { Learning English helps me in my academic study and } \\
\text { for getting a job in the future. }\end{array}$ & & & & & \\
\hline 3 & My teacher of English corrects my errors in a bad way. & & & & & \\
\hline 4 & There are marks for classroom participation in English. & & & & & \\
\hline 5 & I make noticeable errors of grammar and word order when I speak English. & & & & & \\
\hline 6 & Speaking about general topics is easier than talking about a specialized field (e.g.: Politics). & & & & & \\
\hline 7 & My English vocabulary is limited. & & & & & \\
\hline 8 & Two hours of learning English per week is not enough. & & & & & \\
\hline 9 & The time of the English class is not sui table. & & & & & \\
\hline 10 & Lacking specialized vocabulary in the field hinders me to speak freely in English. & & & & & \\
\hline 11 & My teacher of English responds in a friendly way. & & & & & \\
\hline 12 & I don't have the opportunity to speak English outside the classroom. & & & & & \\
\hline 13 & The English class is so over- crowded that the teacher can't pay equal attention to all students. & & & & & \\
\hline 14 & $\begin{array}{l}\text { Our teacher of English gives more importance to reading and writing than to speaking or } \\
\text { listening. }\end{array}$ & & & & & \\
\hline 15 & My teacher of English doesn't allow me to speak Arabic in the English classroom. & & & & & \\
\hline 16 & My teacher of English explains the activities and difficult expressions in Arabic. & & & & & \\
\hline 17 & My teacher of English speaks English exclusively in the class. & & & & & \\
\hline 18 & We benefit $\mathrm{t}$ from a teacher who is specialized in the field (Politics) more than an EFL teacher. & & & & & \\
\hline 19 & The English teacher uses audio-visual aids to help us speak English. & & & & & \\
\hline 20 & The English teacher varies his teaching techniques in teaching the communication skills. & & & & & \\
\hline
\end{tabular}

Indicate your feelings by checking the appropriate box next to each statement. Please give your first reaction to each statement. $($ Strongly agree $=$ SA, Agree $=$ A, Undecided $=U$, Disagree $=\mathrm{D}$, Strongly disagree $=\mathrm{SD}$ )

Thanks for your help

2. Psychological Factors:

Table 2. Psychological Factors causing students' Communication Apprehension (CA)

\begin{tabular}{|c|c|c|c|c|c|c|}
\hline $\mathbf{N}^{\circ}$ & Item & SA (5) & A (4) & $\mathbf{U}(3)$ & D (2) & SD (1) \\
\hline 1 & I prefer talking about general topics rather than a specialized field (Eg: politics). & & & & & \\
\hline 2 & I feel shy to speak English in front of my classmates. & & & & & \\
\hline 3 & I feel shy to speak English in front of male students. & & & & & \\
\hline 4 & I feel shy to speak English in front of female students. & & & & & \\
\hline 5 & I am afraid of making errors when I speak in English. & & & & & \\
\hline 6 & I am a ti mid person by nature and I get nervous easily. & & & & & \\
\hline 7 & I like speaking English in front of my classmates. & & & & & \\
\hline 8 & I feel relaxed to speak English when I prepare. & & & & & \\
\hline 9 & $\begin{array}{l}\text { An EFL teacher can't provide us with sufficient information about our field of study } \\
\text { (compared with a specialized teacher) }\end{array}$ & & & & & \\
\hline 10 & My friends make fun of me when I speak English.. & & & & & \\
\hline 11 & Students are only interested in studying English to pass exams. & & & & & \\
\hline 12 & I like talking with foreign people in English. & & & & & \\
\hline 13 & The English teachers' gender doesn't affect my classroom participation. & & & & & \\
\hline 14 & I feel better to communicate in English with a male instructor. & & & & & \\
\hline 15 & I feel better to communicate in English with a female instructor. & & & & & \\
\hline 16 & $\begin{array}{l}\text { My desire to speak English is more than my desire to write or read } \\
\text { i t. }\end{array}$ & & & & & \\
\hline 17 & In order not to participate in the English class, I like to sit at the back rows. & & & & & \\
\hline 18 & I feel afraid to talk in English with my teacher outside the classroom. & & & & & \\
\hline 19 & Teachers can't be objective when assessing oral tests. & & & & & \\
\hline
\end{tabular}

Thanks for your help 


\section{Appendix 2:}

Teachers Interview:

Dear Colleagues,

Your opinions are highly appreciated to conduct this research as you are directly involved in the ESP teaching and learning process. Please answer all the questions.

1-General information:

1. Your status in the department of Political Sciences:

Part time teacher $\square \quad$ Full time teacher

2. Your degree:

Licence $\square$ Magister $\square$ Doctorat

3. Did you have any pervious ESP training courses?

Yes $\square \quad$ No

4. What is your experience in teaching English?

Table 3. Teachers' Teaching Experience

\begin{tabular}{llll}
\hline Teachers & $\mathbf{1}$ & $\mathbf{2}$ & $\mathbf{4}$ \\
\hline Years of teaching in middle/secondary school & & \\
Years of teaching at university & & \\
$\mathrm{N}^{\circ}$ of years of experience & & \\
\hline
\end{tabular}

5. How many hours are allotted to teaching English in the department of Political sciences?

6. What is the average size of each ESP class?.

7. Do you use any published textbook?

Yes $\square$ No

8. Do you have any special material designed for Political Sciences Students? Yes No

9. The training in oral communication that I received to become a university teacher was sufficient.

Yes

No

2-B. Specific Course Information:

10. Please rank the English skills in importance from 1-4 ( 1 being the most important):
Listening
Speaking
Reading
Writing

11. In which aspects of English do you think students are usually weak?

Table 4. Students' Weakest Aspect

\begin{tabular}{ll}
\hline 1 & General Vocabulary \\
2 & Scientific and technical vocabulary \\
3 & Reading Comprehension \\
4 & Grammar \\
5 & Writing and composition \\
6 & Speaking and conversation skills \\
7 & Sentence structure \\
\hline
\end{tabular}

12. Please choose and rank the 5 biggest handicaps to teaching oral communication in your lessons. (1 being the biggest problem)

-Student conversation ability

-Lack of technical vocabulary

-Student conversation confidence-Student motivation-Student discipline

-Introverted students

-Time constraints in the lesson-The textbook

-Time constraints outside the lesson

-High school entrance exam

-Class size

-Other (please explain)

13. The students study English in order to: (from 1 to 3, 1 being the most important)

-Read and understand text books in their field of study.

-Take part in oral discussion in English

-Understand the lectures and take notes

-To be able to write answers in written exams and tests

14. How do you evaluate your student? 
Oral test $\quad \square \quad$ Written test $\quad \square \quad$ Both

3- Students' psychology and Language Anxiety:

Please answer the questions

Q15: How do you view the role of language anxiety for ESP learners in learning and particularly speaking English language?

Q 16: What kinds of situations and language classroom activities have you found to be anxiety- provoking for the students?

Q 17: What do you think are the causes of students' anxiety while speaking English?

Q18: What are the instructional factors that cause speaking anxiety fro ESP students?

Q 19: What are the psychological factors that cause language anxiety for ESP learners while learning and speaking English? (Students' beliefs, motivation, confidence, expectations, etc.).

Q 20: Which strategies did you use to successfully cope with your students' communication apprehension or speaking anxiety?

Thank you for your assistance with this research project

\section{References}

[1] Stanga KG, Ladd RT, (1990). Oral Communication Apprehension in Beginning Accounting Majors: An Exploratory Study. Issues in Accounting Education, 5, 180194.

[2] Berger, McCroskey \& Baldwin (1984). Reducing Communication Apprehension: Is there a Better Way? American Journal of Pharmaceutical Education, 48, Spring (1984) Retrieved from www.jamesmccroskey.com/publications/117.pdf.

[3] McCroskey, J. C., \& Richmond, V. P. (1995). Correlates of Compulsive Communication: Quantitative and Qualitative Characterizations. Communication Quarterly, 43, 39-52.

[4] MacIntyre, P. D., \& Gardner. (1991). Methods and Results in the Study of Anxiety and Language Learning: A Review of Literature. Language Learning Journal, 41 (1), 85-117. Retrieved February, 17, 2016, from: http://faculty.uccb.ns.ca/pmacintyre/research_pages/journals/ methods/results1991.pdf.

[5] Strevens, P, (1978). The Nature of Language Teaching, In Jack Richards (ed), Understanding Second and Foreign Language Learning, Rowley, Mass.: Newbury House, 178-203.

[6] Izzo, S. (1981). Second Language Learning: A Review of Related Studies, Rosslyn, Virginia (USA),. Inter America Research Associates, Inc.: Natioanl Clearing Housefor Bilingual Education).

[7] Stevens, V. (1989): A Direction for Call: From Behavioristic to Humanistic Courseware, Teaching Language With Computers. California: Martha C. Pennington (ed), 31-43.

[8] Price, M., L. (1991). The Subjective Experience of Foreign Language Anxiety: Interviews with Anxious Students; in Horwitz E., K. and D., J. Young (eds.). Englewood Cliffs, NJ: Prentice Hall, (1991), 101-108.

[9] Horwitz, E. K., Horwitz, M. B., \& Cope, J. (1986): Foreign Language Communication Apprehension. The Modem Language Journal, 70, 125-132.

[10] Krashen, S. (1982). Principles and Practice in Second Language Acquisition, Oxford: Pergamon. 